\title{
Hypotaurine and thiotaurine as indicators of sulfide exposure in bivalves and vestimentiferans from hydrothermal vents and cold seeps
}

\author{
Garth L. Brand ${ }^{1}$, Robin V. Horak ${ }^{1,2}$, Nadine Le Bris ${ }^{3}$, Shana K. Goffredi ${ }^{4}$, Susan L. Carney ${ }^{5,6}$, Breea \\ Govenar $^{5,7}$, and Paul H. Yancey ${ }^{1, *}$
}

\author{
${ }^{1}$ Biology Department, Whitman College, Walla Walla, WA 99362 USA \\ ${ }^{2}$ Thomas Jefferson University, Philadelphia, PA 19107 USA \\ ${ }^{3}$ IFREMER Departement Eude des Ecosystèmes Profonds, BP 70, 29280, Plouzane FRANCE \\ ${ }^{4}$ Monterey Bay Aquarium Research Institute, Moss Landing, CA 93905 USA, and California Institute of \\ Technology, Pasadena, CA 91125 USA \\ ${ }^{5}$ The Pennsylvania State University, Department of Biology, University Park, PA 16802 USA \\ ${ }^{6}$ Mote Marine Laboratory, Sarasota, FL 34236 USA \\ ${ }^{7}$ Woods Hole Oceanographic Institution, Woods Hole, MA 02543 USA
}

\author{
*: Corresponding author : Paul H. Yancey, Biology Department, Whitman College, Walla Walla, WA 99362 U.S.A. \\ e-mail address : yancey@whitman.edu; tel.: 509 527-5498; fax: 509 527-5904
}

\begin{abstract}
:
Vesicomyid clams, vestimentiferans, and some bathymodiolin mussels from hydrothermal vents and cold seeps possess thiotrophic endosymbionts, high levels of hypotaurine and, in tissues with symbionts, thiotaurine. The latter, a product of hypotaurine and sulfide, may store and/or transport sulfide non-toxically, and the ratio to hypotaurine plus thiotaurine $(\mathrm{Th} /[\mathrm{H}+\mathrm{Th}])$ may reflect an animal's sulfide exposure. To test this, we analyzed seep and vent animals with in situ sulfide measurements. Calyptogena kilmeri clams occur at high-sulfide seeps in Monterey Canyon, while C. (Vesicomya) pacifica clams occur at seeps with lower levels but take up and metabolize sulfide more effectively. From one seep where they co-occur, both had gill thiotaurine contents at $22-25 \mathrm{mmol} / \mathrm{kg}$ wet mass, and while C. (V.) pacifica had a higher blood sulfide level, it had a lower $\mathrm{Th} /[\mathrm{H}+\mathrm{Th}](0.39)$ than $\mathrm{C}$. kilmeri (0.63). However, these same species from different seeps with lower sulfide exposures had lower ratios. Bathymodiolus thermophilus (East Pacific Rise [EPR $\left.\left.9^{\circ} 50^{\prime} \mathrm{N}\right]\right)$ from high- $(84 \mu \mathrm{M})$ and a low- $(7 \mu \mathrm{M})$ sulfide vents had gill ratios of 0.40 and 0.12 , respectively. Trophosomes of Riftia pachyptila (EPR $\left.9^{\circ} 50^{\prime} \mathrm{N}\right)$ from medium- $(33 \mu \mathrm{M})$ and low- $(4 \mu \mathrm{M})$ sulfide vents had ratios of 0.23 and 0.20 , respectively (not significantly different). Ridgeia piscesae vestimentiferans (Juan de Fuca Ridge) have very different phenotypes at high- and low-sulfide sites, and their trophosomes had the greatest differences: 0.81 and 0.04 ratios from high- and low-sulfide sites, respectively. Thus $\mathrm{Th} /[\mathrm{H}+\mathrm{Th}]$ may indicate sulfide exposure levels within species, but not in interspecies comparisons, possibly due to phylogenetic and metabolic differences. Total $\mathrm{H}+\mathrm{Th}$ was constant within each species (except in R. piscesae); the sum may indicate the maximum potential sulfide load that a species faces.
\end{abstract}

Keywords: hypotaurine, thiotaurine, taurine, vestimentiferan, bathymodiolin, vesicomyid 


\section{Problem}

Certain animals around marine hydrothermal vents and cold seeps have formed a symbiotic relationship with chemosynthetic microbes. In particular, vesicomyid clams, vestimentiferans, and some bathymodiolin mussels take up hydrogen sulfide from vent or seep emissions for thiotrophic endosymbionts. These endosymbionts oxidize the sulfide ultimately to drive organic carbon fixation (Van Dover \& Fry 1994). However, hydrogen sulfide is toxic to animals because it can bind to iron and disrupt mitochondrial function (Fisher 1990). Some of these animals have special sulfide binding proteins (e.g., modified hemoglobins) in their blood or hemolymph for transporting sulfide non-toxically from the environment to the symbionts (Arp et al. 1987; Childress et al. 1993; Kraus 1995; Zal et al. 2000). However, these proteins do not transport sulfide within cells (with the exception of intracellular hemoglobins reported in Solemya clams: Kraus et al. 1996), and other mechanisms of intracellular defense against sulfide have been proposed. For example, there are specialized sulfide-oxidizing organelles in epidermal tissue in some polychaetes including vestimentiferans (Menon et al. 2003). In some species such as the vent mussel Bathymodiolus thermophilus, sulfide is rapidly converted to thiosulfate as a means of detoxification (Powell \& Somero 1986). Elemental sulfur has also been found in many of these animals; it has been proposed to be a non-toxic energy reserve produced by the bacteria (Vetter 1985; Arndt et al. 2001).

In recent years, another mechanism involving thiotaurine and hypotaurine has been proposed to serve in protection from and/or transport of sulfide (Alberic \& Boulegue 1990; Pranal et al. 1995; Pruski et al. 2000b). These unusual amino acids can be found at high levels in many vestimentiferans and bivalves from vents and seeps (Alberic 1986; Pranal et al. 1995; Pruski et al. 2000a). They are generally found only at low levels in hemolymph or blood, and thus are assumed to be primarily intracellular (Pruski et al. 2000a, Yin et al. 2000). In tissues with endosymbionts, hypotaurine appears to react with sulfide to produce thiotaurine (Pruski et al. 2000b):

$$
\text { (hypotaurine) }{ }^{+} \mathrm{NH}_{3}-\mathrm{CH}_{2}-\mathrm{CH}_{2}-\mathrm{SO}_{2}^{-}+\mathrm{SH}_{-->}{ }^{+} \mathrm{NH}_{3}-\mathrm{CH}_{2}-\mathrm{CH}_{2}-\mathrm{SO}^{-}{ }_{2}-\mathrm{SH} \text { (thiotaurine) }
$$

The source of $\mathrm{SH}$ could be a free radical, a ligand donated by a carrier protein $\mathrm{R}$ as $\mathrm{R}$-SSH, or a group donated by glutathione-SSH or other thiols. Synthesis of thiotaurine appears to be enzymatic (Pruski \& Fiala-Medioni 2003). The reaction is reversible, and might serve to store sulfide non-toxically within cells, then release it as the endosymbionts deplete free sulfide. This would be advantageous as sulfide concentration surrounding the animals can vary (Barry et al. 1996; Shank et al. 1998).

As evidence for the linkage between the thiotaurine reaction and symbiosis, hypotaurine is high in all tissues in these animals but thiotaurine occurs at high levels only in thiotrophic symbiont-bearing tissues, namely gills in some bivalves and trophosomes in vestimentiferans (Pruski et al. 2000a; Fiess et al. 2002). As a contrasting example, thiotaurine is very low in gills of methanotrophic mussels from cold seeps (Pruski et al. 2000b). The ratio of thiotaurine to total hypotaurine plus thiotaurine (Th/[H+Th]) has been proposed to be an indicator of the level of sulfide exposure in these animals (Pranal et al. 1995) and thiotaurine has been proposed to be a general marker of thiotrophic endosymbiosis (Pruski et al. 2000b). Indeed, the ratio tends to be higher in animals with higher environmental exposures to sulfide (Pruski et al. 2000a). Also, laboratory studies show that thiotaurine contents increase during sulfide exposure in symbiont-bearing tissues of vesicomyids, bathymodiolins, vestimentiferans (Pruski \& Fiala-Médioni 2003) and shallow-living solemyid clams (Joyner et al. 2003).

The role of thiotaurine has recently been expanded by the discovery that two species of gastropods from hydrothermal vents contain substantial levels of thiotaurine (Rosenberg et al. 2006), even though they lack endosymbionts. Nevertheless, the $\mathrm{Th} /[\mathrm{H}+\mathrm{Th}]$ ratio decreased in gastropods held in the lab with low or no sulfide while it stayed high in individuals held with high sulfide. These gastropods may be exposed to sulfide as a result of grazing on vent bacteria, and the thiotaurine finding supports the idea that this solute is used for sulfide detoxification and not necessarily for symbiosis.

The question addressed here is whether thiotaurine is made by vent and seep animals in situ in proportion to sulfide exposure, and thus whether an estimate of in situ sulfide exposure can be made on fieldcollected samples by analyzing thiotaurine and hypotaurine contents (which can be easier to measure than sulfide). To date, the best correlations between sulfide exposure and thiotaurine have come from laboratory studies; correlations between amino acids and sulfide levels in situ have only been made with specimens not from the same time or site as the sulfide measurements. Here we have analyzed these 
amino acids in a variety of vent and seep animals (originally collected for other studies) most of which had associated ambient sulfide values (and blood/hemolymph measurements for some).

First, the vesicomyid seep clams Calyptogena/Vesicomya pacifica, C. kilmeri, and Ectengena extenta were analyzed. C. (V.) pacifica and C. kilmeri are the dominant vesicomyids at many cold seeps in Monterey Canyon off California. The two can be found living together, though one species dominates at certain locations; $C$. kilmeri prefers areas of high sulfide in the sediment, generally 4-18 mM, whereas $C$. (V.) pacifica is found in areas with lower sulfide levels, from trace levels to $4 \mathrm{mM}$ (Barry et al. 1996, 1997). These differences are attributed to physiological and biochemical adaptations that give $C$. (V.) pacifica a much higher efficiency in both the uptake of sulfide through the foot and the oxidation of sulfide in the gills (Goffredi et al. 2002). C. kilmeri in contrast has lower uptake and oxidation activity, presumably reflecting its need for higher sulfide environments. Specimens of both species were obtained from the same seep and from different seeps, along with measurements of sulfide levels in the sediment and/or the hemolymph (blood) (Goffredi et al. 2002).

Ectengena extenta, closely related to C. kilmeri according to molecular analysis (Peek et al. 1998), was collected at deep seeps $(3200 \mathrm{~m})$ in Monterey Canyon. Its sulfide exposure is unknown, but its gills have much higher levels of elemental sulfur $\left(S^{0}\right)$ than the other vesicomyids (Goffredi et al. 2004). Elemental sulfur has been proposed to be an energy reserve (as noted earlier), produced aerobically and then possibly used during anoxia (Vetter 1985; Arndt et al. 2001); it may be particularly important in animals most frequently experiencing the anoxia associated with sulfide-laden waters.

The second type of animal analyzed was the bathymodiolin mussel Bathymodiolus thermophilus, collected from two different locations within a hydrothermal vent site on the East Pacific Rise. Precise sulfide measurements in the water were also made near the animals. Bathymodiolins can have one or both of two different symbionts that specialize on either sulfide or methane for chemosynthesis (Distel et al. 1995), although in previous work only the thiotrophic symbiont was found in B. thermophilus (Fisher et al. 1987). The mussels can also obtain nutrients through filter feeding (Page et al. 1991); thus they may have lower overall sulfide usage, which could explain their relatively low hypotaurine and thiotaurine contents (Pruski et al. 2000b).

Vestimentiferans were the final type of symbiotic animal analyzed. Specimens of the giant tubeworm Riftia pachyptila were collected from two very different vent sites on the East Pacific Rise (Govenar et al. 2005); sulfide measurements were made in the water near their plumes and at the base of their tubes. Ridgeia piscesae vestimentiferans were taken from two very different habitats on the Juan de Fuca Ridge. This tubeworm can exhibit very distinct phenotypes, depending on the local habitat and possibly sulfideacquisition strategies. Although sulfide levels were not available for the Ridgeia specimens used here, the two collection sites are known to have very different sulfide levels (Urcuyo et al. 2003). Animals at diffuseflow basalt sites are exposed to low sulfide and generally have a characteristic "long-skinny" (LS) morphology, while animals from a high-sulfide chimney have a "short-fat" (SF) body (Robigou et al. 1993; Sarrazin et al. 1997; Urcuyo et al. 1998; 2003). The morphologies are so different that they were once considered to be separate species, but genomic analyses have revealed them to be the same (Southward et al. 1995, 1996; Black et al. 1997, 1998; Carney et al. 2002). Both LS and SF types were used in this study.

Thiotaurine and hypotaurine are closely related to taurine, an amino acid often found as a major organic osmolyte in shallow-water invertebrates. Like all osmoconforming marine invertebrates, cells of polychaetes and mollusks accumulate free amino acids, methylamines and sometimes polyols to equalize their cellular osmotic pressures with that of the extracellular fluid and seawater. These organic osmolytes often have other cytoprotective functions beyond providing osmotic balance, and vary in composition in correlation with metabolic adaptations, temperature, and ocean depth (Yancey et al. 2002; Yancey 2005). Taurine contents, for example, decline with ocean depth (at least in bivalves, gastropods and anthozoans; Pruski et al. 2000a; Fiess et al. 2002; Yancey et al. 2002, 2004; Rosenberg et al. 2006). In general taurine levels have not been found to shift with changing sulfide exposure, but Joyner et al. (2003) recently found changes in taurine as well as hypotaurine and thiotaurine in shallow symbiotic clams. Therefore, contents of taurine, as well as other major sulfur-containing organic solutes, were also measured in all specimens to determine whether there were any trends. 


\title{
2. Study Areas
}

Animals were collected from, and sulfide measurements were made at 1) Monterey Canyon (California) cold seeps, including Clam Field ( $36^{\circ} 44.0^{\prime} \mathrm{N}, 122^{\circ} 2.0^{\prime} \mathrm{W}$; $950 \mathrm{~m}$ depth) on January 5, 1999, Invert Cliff (1000 m) on September 21, 1999, and Crescent Slump (3200 m) on November 3, 2000, 2) Eel River cold seeps off Eureka, California (510-520 m depth), on April 29, 2001, 3) hydrothermal vents (2500-2550 m depth) at the Mussel Bed (December 10 to 12, 2002), Tica (December 1 to 14, 2002) and Riftia Fields (December 1 to 11,2002 ) sites in the $9^{\circ} 50^{\prime} \mathrm{N}$ area of the East-Pacific Rise (EPR), and 4) the Main Endeavour Field of the Juan de Fuca Ridge on May 12, 2001, at the Clam Bed site $\left(47^{\circ} 57^{\prime} \mathrm{N}, 129^{\circ} 05^{\prime} \mathrm{W}\right.$; $2194 \mathrm{~m}$ depth) and on May 10, 2001, at the Smoke and Mirrors sulfide edifice called Strawberry Fields ( $47^{\circ} 56^{\prime} \mathrm{N}, 128^{\circ} 05^{\prime} \mathrm{W} ; 2184 \mathrm{~m}$ depth).

\section{Materials and Methods}

\begin{abstract}
Specimen Collection
Specimens were collected using various remotely operated vehicles (ROVs) from several locations, most originally for other studies. Calyptogena (Vesicomya) pacifica were collected at Clam Field (Monterey Canyon) and Eel River seeps, and C. kilmeri from Clam Field and Invert Cliff (Monterey). Ectengena extenta were from the Crescent Slump (Monterey) seeps. Riftia pachyptila were collected at Tica and Riftia Field vents (9 ${ }^{\circ} 50^{\prime} \mathrm{N}$ EPR). Bathymodiolus thermophilus were collected at two different locations in the Mussel Bed vents (9 $9^{\circ} 0^{\prime}$ N EPR). Ridgeia piscesae were collected from Main Endeavour Field of the Juan de Fuca Ridge. Those from the low-sulfide Clam Bed site had the LS morphology, while those from the high-sulfide Strawberry Fields edifice had the SF morphology (see Problem section).

Some animals were immediately frozen on the ship, while others were kept alive in chilled $\left(4^{\circ} \mathrm{C}\right)$ seawater on the ship, then later were either frozen or dissected for tissues that were immediately frozen. Freezing was at $-70^{\circ} \mathrm{C}$ or on dry ice on the ship, followed by storage at -70 to $-80^{\circ} \mathrm{C}$ in the laboratory.

\section{Sulfide analysis}

For $C$. (V.) pacifica and C. kilmeri from Monterey Canyon, sulfide levels $\left(\sum \mathrm{H}_{2} \mathrm{~S}\right)$ in the sediment pore water and in their hemolymphs were measured in a previous study by gas chromatography (for the same specimens used here) (Goffredi et al. 2002). For pacifica specimens from Eel River seeps, sulfide levels in sediment pore water at the collection site were determined by W. Ziebis using an amperometric sensor (published in Levin et al. 2003). Total concentrations of acid volatile sulfide in the environment of $R$. pachyptila and B. thermophilus were determined in situ as described in Le Bris et al. (2006), using the submersible flow analyzer ALCHIMIST installed on the DSRV Alvin. Large spatial gradients were observed at the scale of tubeworms (Le Bris et al. 2006). Only the measurements obtained at the level of plumes were considered for this study, as the most relevant of sulfide exposure.
\end{abstract}

\section{Amino Acid Analysis}

Samples were shipped on dry ice to Whitman College where they were stored at $-70^{\circ} \mathrm{C}$ until analysis. Frozen samples were weighed then rapidly homogenized in a glass dounce on ice in $1 \mathrm{ml}$ of $70 \%$ cold ethanol, and kept on ice for at least 3 hours before centrifugation at $15000 \times \mathrm{g}$ for 20 minutes to remove proteins. Ethanol precipitation of unwanted proteins was used rather than the more common acid precipitation because acid degrades thiotaurine (Pruski et al. 2000b). Supernatants were dried overnight in a vacuum centrifuge then resuspended in 500 to $1000 \mu \mathrm{l}$ of purified water. All samples were passed through C-18 delipidizing cartridges (Varian, Inc.) and 0.45 micron filters (Millipore, Inc.) as described by Wolff et al. (1989). Samples were then analyzed for amino acids using high performance liquid chromatography (HPLC) as previously described (Wolff et al. 1989; Yin et al. 2000). Thiotaurine standard was synthesized by the method of Cavalini et al. (1963). 
Statistical Analysis

Data are presented as means \pm S.D. Statistical significance $(P<0.5)$ was determined using Student's ttests or ANOVA with Student-Newmann-Keuls post-tests. Arcsin conversions were used for statistics of ratios.

\section{Results}

Vesicomyids: Thiotaurine and Hypotaurine

Thiotaurine was found at substantial levels in vesicomyid gills, with values ranging from about 6.9 to 70 $\mathrm{mmol} / \mathrm{kg}$ wet mass (Table 1, top rows). For C. (V.) pacifica, specimens from the site (Clam Field) with 4 $\mathrm{mM}$ ambient sulfide were compared to ones from the site (Eel River) with $\leq 2 \mathrm{mM}$ ambient sulfide (Table 1). The former had higher thiotaurine (22.3 vs. 6.9) and lower hypotaurine (36.6 vs. 56.6), and thus a higher $\mathrm{Th} /[\mathrm{H}+\mathrm{Th}]$ ratio (0.39 vs 0.11 ). For $C$. kilmeri, specimens from the site (Clam Field) with $4 \mathrm{mM}$ ambient sulfide and average of $1.1 \mathrm{mM}$ blood (hemolymph) levels were compared to ones from the site (Invert Cliff) with higher (7-9 mM) ambient sulfide but lower blood levels (about 0.6 mM) (Table 1). The former had higher thiotaurine (25.2 vs 13.1 ) and lower hypotaurine (14.5 vs 21.8$)$, and thus a higher $\mathrm{Th} /[\mathrm{H}+\mathrm{Th}]$ ratio (0.63 vs 0.39 ) (Table 1 and Fig. 1$)$.

Interspecies comparisons yielded a different pattern for $C$. ( $V$.) pacifica and $C$. kilmeri from the same site (Clam Field seep). C. (V.) pacifica had significantly higher blood levels of sulfide than C. kilmeri (2.7 vs $1.1 \mathrm{mM}$ ), yet the two species had statistically the same thiotaurine levels at 22.3 and $25.1 \mathrm{mmol} / \mathrm{kg}$, respectively (Table 1$)$. Moreover, $C$. (V.) pacifica had a lower $\mathrm{Th} /[\mathrm{H}+\mathrm{Th}]$ ratio than $C$. kilmeri $(0.39$ vs. 0.63) (Table 1 and Fig. 1).

Ectengena extenta clams (not shown in Table 1) had the highest content of gill thiotaurine $(70.5 \pm$ $5.9 \mathrm{mmol} / \mathrm{kg})$, lowest content of hypotaurine $(7.2 \pm 0.7)$ and highest $\mathrm{Th} /[\mathrm{H}+\mathrm{Th}]$ ratio, at $0.91 \pm 0.004$.

For the two species from Clam Field, foot tissue was also available for analysis (Table 2). Thiotaurine was extremely low in both, while hypotaurine was found at moderate levels that were lower than in gills (Table 1),

\section{Bathymodiolins: Thiotaurine and Hypotaurine}

In Bathymodiolus thermophilus mussels from the EPR Mussel Bed site, both thiotaurine and hypotaurine were found at substantial levels in gill tissue (Table 1, middle rows). Mussels from the two collection sites were exposed to ambient waters with $84 \mu \mathrm{M}$ and $7 \mu \mathrm{M}$ sulfide, respectively. The former had higher thiotaurine (7.8 vs $3.1 \mathrm{mmol} / \mathrm{kg}$ wet mass.), lower hypotaurine (12.2 vs 21.0$)$, and a higher ratio (0.40 vs 0.12) (Table 1 and Fig. 1).

For foot tissue (Table 2; available for the low-sulfide group). thiotaurine was not statistically different than zero, but hypotaurine contents were the same as in gills (Table 1 ).

\section{Vestimentiferans: Thiotaurine and Hypotaurine}

In the Riftia pachyptila tubeworms from the EPR sites, thiotaurine levels were high in the trophosome (Table 1, lower middle rows). Worms from the two collections sites, Tica and Riftia Field, were exposed to different levels of sulfide: at the tube bases, the maximum ambient values were 283 and $81 \mu \mathrm{M}$, respectively, however at plume level the averages were $33 \mu \mathrm{M}$ and $4 \mu \mathrm{M}$ sulfide, respectively. The two groups showed no statistical differences: the averages for the Tica and Rifia Field groups were, respectively, 16.5 and $14.8 \mathrm{mmol} / \mathrm{kg}$ wet mass. for thiotaurine, 55.1 and 59.4 for hypotaurine, and 0.23 and 0.20 for the $\mathrm{Th} /[\mathrm{H}+\mathrm{Th}]$ ratio (Table 1 and Fig. 1).

In the Ridgeia piscesae tubeworms from Juan de Fuca vents, trophosomes varied greatly between the SF form, living on high-sulfide chimneys, and the LS form, living at a diffuse-flow basalt site (Table 1, lower rows). The SF trophosomes were greener than the LS ones, and the SF ethanol extracts were much darker in greenish-yellow color. In comparison to the LS group, the SF group had much higher thiotaurine content (49 vs $0.77 \mathrm{mmol} / \mathrm{kg}$ wet mass.), lower hypotaurine content (11 vs 17), and a much higher Th/[H+Th] ratio (0.81 vs 0.04 ) (Table 1 and Fig. 1 ). 
Vestimentum and plume tissue from Riftia pachyptila were also analyzed (Table 2); these contained levels of thiotaurine considerably lower than in trophosomes (Table 1), but had high levels of hypotaurine.

\section{All Species: Total Thiotaurine plus Hypotaurine}

Totals of thiotaurine and hypotaurine contents of all specimens were calculated for symbiont-bearing tissues, and the results are shown Table 1 (third to last column) and Fig. 2. Values did not differ within most species, even in those in which hypotaurine and thiotaurine differed considerably between test groups. The only exception to this was Ridgeia piscesae, in which the total was $60 \mathrm{mmol} / \mathrm{kg}$ wet mass in the high-sulfide SF groups and $18 \mathrm{mmol} / \mathrm{kg}$ wet mass in the low-sulfide LS group.

\section{All Species: Taurine}

Taurine contents of all specimens are shown in the second-to-last column of Tables 1 and 2. For symbiont-bearing tissues (Table 1), values did not differ within species, even in those in which hypotaurine and thiotaurine differed considerably between test groups. Contents correlated inversely with depth of collection, consistent with previous studies. The vesicomyid clams from Eel River seeps at $0.5 \mathrm{~km}$ had 49 $\mathrm{mmol} / \mathrm{kg}$ wet mass; the two vesicomyid species from Monterey Canyon from about $1 \mathrm{~km}$ depth had taurine contents of about $37-41 \mathrm{mmol} / \mathrm{kg}$ wet mass. (Table 1). Ridgeia piscesae were from $\sim 2.1 \mathrm{~km}$ and had contents of about 29-33 mmol/kg wt wt. Both Riftia pachyptila and Bathymodiolus thermophilus were from 2.5 to $2.55 \mathrm{~km}$, and had contents ranging from about 11 to $15 \mathrm{mmol} / \mathrm{kg}$ wet mass. Finally, the deepest species, Ectengena extenta from $3.2 \mathrm{~km}$, had contents of $10 \mathrm{mmol} / \mathrm{kg}$ wet mass (not shown in Table 1)

\section{All Species: Other Osmotically Significant Organic Solutes}

The HPLC method revealed a number of other low-molecular-weight organic solutes at medium to high concentrations in all tissues. These solutes are presumed to serve as organic osmolytes, though they may have other functions. Some of these contained sulfur in vestimentiferans, as follows. In Riftia pachyptila trophosomes, an unknown tentatively identified as N-methylhypotaurine (Yin et al. 2000) was found at estimated levels of $15.0 \pm 3.3$ and $13.8 \pm 1.5 \mathrm{mmol} / \mathrm{kg}$ wet mass in medium- and low-sulfide specimens, respectively (not significantly different). In Ridgeia piscesae trophosomes, for SF and LS phenotypes, respectively, N-methyltaurine (Yin et al. 2000) was found at $14.0 \pm 6.5$ and $11.6 \pm 3.1 \mathrm{mmol} / \mathrm{kg}$ wet mass (not significantly different) and $\mathrm{N}$-methylhypotaurine ate $14.4 \pm 4 . \overline{4}$ and $28.1 \pm 1.1 \mathrm{mmol} / \mathrm{kg}(P<0.05)$. All tissues in all species also contained cysteine and methionine but at low levels $(<1 \mathrm{mmol} / \mathrm{kg})$ that did not vary between test groups within species. Similar results were found for other tissues without symbionts (gill, foot, plume).

The other major organic solutes in all tissues analyzed were glycine betaine (GB) and glycine in most species, and (in decreasing order) alanine, proline and GB in vestimentiferans. The sum total of these solutes plus the methylated taurine derivatives are shown in the final columns of Tables 1 and 2. $B$. thermophilus tissues also contained substantial amounts of a solute that did not differ in HPLC peak area between groups. It reacted positively with ninhydrin, indicating an amine, but its elution time did not match any amino acid standard. Thus it could not be quantified.

\section{Discussion}

As found in previous studies, thiotaurine was considerably higher in tissues with symbionts (Table 1) than tissues without (Table 2). Our data for the symbiont-bearing tissues are generally consistent with the hypothesis that $\mathrm{Th} /[\mathrm{H}+\mathrm{Th}]$ ratios give an indication of sulfide exposure (Pranal et al. 1995; Pruski et al. $2000 b)$ within species. However the ratios may not be useful for interspecies comparisons. We propose that a different parameter, the sum of hypotaurine and thiotaurine $(\mathrm{H}+\mathrm{Th})$, is a consistent and useful indicator of maximum sulfide exposure across species.

$\mathrm{Th} /[\mathrm{H}+\mathrm{Th}]$ Ratio as an Indicator of Current Exposure As predicted by the hypothesis, the $\mathrm{Th} /[\mathrm{H}+\mathrm{Th}]$ ratio was lower in symbiont-bearing tissues within most species in each group having the lower sulfide exposure (Table 1, Fig. 1). In Calyptogena (Vesicomya) pacifica, the correlation of the ratio to sulfide exposure was found for both sediment and blood/hemolymph 
sulfide levels. For C. kilmeri, the correlation was with the internal (blood/hemolymph) sulfide level only, a result suggests that internal sulfide may be a better indicator of in situ exposure than ambient sulfide. Thus, in future studies, measurements of internal sulfide will be needed. For the other species, blood/hemolymph values were not available, but the differences in ambient sulfide were mostly large enough that it seems reasonable to assume that these values reflect internal exposure. Indeed, earlier work on Riftia pachyptila found that internal sulfide levels were linked to total ambient sulfide concentrations (Goffredi et al. 1997). For Ridgeia piscesae, precise sulfide exposures were not available for these specimens, but the large sulfide differences between the habitats for the LF and SF phenotypes are well known (Robigou et al. 1993; Sarrazin et al. 1997; Urcuyo et al. 1998, 2003). For example, in one study an aggregate of LF forms was exposed (at plume level) to a mean sulfide concentration of $0.1 \mu \mathrm{M}$ (Urcuyo et al. 2003). Moreover, the different intensities of greenish color we noted for the SF and LF trophosomes may be a marker of different sulfide exposures, because greenish color is highly correlated with tissue contents of elemental sulfur (Pflugfelder et al. 2005).

The exception was Riftia pachyptila, in which the difference between ratios was not significant. While the two sites, Tica and Riftia Field, differ considerably in their overall chemistry including maximum ambient sulfide levels (Govenar et al. 2005), the magnitude and absolute difference in sulfide exposures between the two groups at plume level were considerably lower than for the other animals (Table 1). It is possible that the tubeworms were collected during a period of relatively low sulfide exposure; for example in another study, sulfide levels at Riftia base level ranged from 190 to $980 \mu \mathrm{M}$ (Shank et al. 1998), compared to $81-283 \mu \mathrm{M}$ in this study. Furthermore, in previous studies, these animals typically had higher $\mathrm{Th} /[\mathrm{H}+\mathrm{Th}]$ ratios (e.g., 0.55; Pruski et al. 2000a). Thus our data for Riftia do not contradict the hypothesis. However, our data suggest that the ratio may only be a useful indicator between groups subjected to large differences in exposure.

While $\mathrm{Th} /[\mathrm{H}+\mathrm{Th}]$ ratio may thus be useful as a rough indicator of exposure for intraspecies studies in some cases, it cannot be readily used for interspecies comparisons. This is most clearly shown in the data for $C$. (V.) pacifica vs C. kilmeri. For specimens from the same seep (Clam Field), the former had much higher blood sulfide levels (2.7 vs $1.1 \mathrm{mM}$ ), but had a much lower $\mathrm{Th} /[\mathrm{H}+\mathrm{Th}]$ ratio (0.39 vs 0.63$)$, and both had about the same content of thiotaurine (Table 1). Possibly the ratio also reflects the metabolic turnover rate of sulfide, which is much higher in C. (V.) pacifica than in C. kilmeri (Goffredi et al. 2002).

\section{Total Hypotaurine plus Thiotaurine as an Indicator of Maximum Exposure}

This study revealed for the first time that a different parameter, total $\mathrm{H}+\mathrm{Th}$, may be consistent within most species, regardless of exposure and individual thiotaurine and hypotaurine levels (Fig. 2). We propose that $\mathrm{H}+\mathrm{Th}$ is an indicator of potential sulfide load. That is, a species which may sometimes experience high internal sulfide loads may need to have a high reserve of hypotaurine for converting the sulfide to thiotaurine, regardless of sulfide exposure in any given period. This hypothesis is supported not only by the totals themselves but by these species features and differences:

1) Calyptogena (Vesicomya) pacifica vs C. kilmeri. The former had much higher $\mathrm{H}+\mathrm{Th}$ totals (Fig. 2) despite having lower Th/[H+Th] ratios (Fig. 1). This is consistent with their very different metabolic adaptations. C. (V.) pacifica routinely has much higher blood sulfide levels than C. kilmeri, as in the specimens used here at a seep where both were exposed to sulfide up to $4 \mathrm{mM}$ (Table 1 ). The difference is due to a variety of $C$. (V.) pacifica adaptations including a larger foot (which takes up sulfide from the environment), larger plasma volume, and higher concentration of zinc (which binds sulfide in transport proteins) (Goffredi et al. 2002). Moreover, other specimens of $C$. kilmeri from high-sulfide seeps (9-18 mM) had blood/hemolymph sulfide levels much lower than those of $C$. (V.) pacifica at the Clam Field (4 mM) seep (Goffredi et al. 2002). Thus, the high levels of hypotaurine in C. (V.) pacifica may be produced so that it can be converted to thiotaurine in certain conditions. For example, if internal sulfide levels rise during some conditions, thiotaurine production could increase temporarily to prevent sulfide toxicity and/or to provide an energy reserve for periods of lower sulfide availability.

2) Bathymodiolus thermophilus: while one group of these mussels had a fairly high $\mathrm{T} /[\mathrm{H}+\mathrm{Th}]$ ratio of 0.40 , both groups had some of the lowest total $\mathrm{H}+\mathrm{Th}$ of all species in this study, along with the LS-type Ridgeia piscesae (Figs 1, 2). The low $\mathrm{H}+\mathrm{Th}$ is consistent with this species' relatively low energy input from its thiotrophic symbionts, as indicated by its lack of elemental sulfur in its gills and low activity of symbiont enzymes (Fisher et al. 1987; Felbeck et al. 1981).

3) Riftia pachyptila: the specimens here had fairly low $\mathrm{T} /[\mathrm{H}+\mathrm{Th}]$ ratios, consistent with their relatively low sulfide exposures $(4-33 \mu \mathrm{M})$. However, their $\mathrm{H}+\mathrm{Th}$ values were among the highest (Figs 1, 2). This could 
be a general species adaptation that allows the worms to tolerate much higher sulfide exposures than the specimens used here (e.g., Shank et al. 1998). Indeed, blood levels of sulfide have been found in Riftia at $3.3 \mathrm{mM}$ (Childress et al. 1984), higher than those of $C$. (V.) pacifica (Table 1), which had somewhat lower $\mathrm{H}+\mathrm{Th}$ values (Fig. 2). Overall, the low $\mathrm{T} /[\mathrm{H}+\mathrm{Th}]$ ratio combined with a high total $\mathrm{H}+\mathrm{Th}$ in these Riftia specimens is consistent with the hypotheses that the ratio is indicative of recent exposure and that the total correlates with maximum exposure.

4) Ridgeia piscesae: the pattern in this species for $\mathrm{H}+\mathrm{Th}$ was unlike that of the other species, since the values were dramatically different between the SF and LS phenotypes (Fig. 2). However, this is not necessarily inconsistent with our hypothesis that $\mathrm{H}+\mathrm{Th}$ relates to maximum exposure. These two phenotypes are so different that they were once thought to be separate species, and expression of some of their genes has been shown to be quite different between the two forms, and even within a form depending upon collection site (Carney et al. submitted). Thus it is possible that, in addition to altered gene expression for very different body forms, gene regulation related to hypotaurine-thiotaurine levels is also adjusted to reflect the maximum exposures in the very different habitats. Additionally, the Ridgeia piscesae forms have very different sulfide acquisition strategies. The LS growth form likely takes in sulfide from thin, sulfide-permeable posterior extensions (roots) of its tube (Urcuyo et al. 2003) while the SF form, without posterior roots, takes in sulfide through the plume as Riftia does. While sulfide levels within the substrate may be in the range of $100 \mu \mathrm{M}$ (Urcuyo et al. 2003) for the LS animals, these animals' exposure to sulfide through their roots may be limited by a surface area that is smaller than that of the plumes of the SF form.

5) In addition to the species for which we had sulfide data, Ectengena extenta had high levels of elemental sulfur in their gills, suggesting a very high level of sulfide exposure (as noted earlier). Their gills also had both the highest $\mathrm{T} /[\mathrm{H}+\mathrm{Th}]$ ratio and $\mathrm{H}+\mathrm{Th}$ total. The idea that high total $\mathrm{H}+\mathrm{Th}$ is a marker of maximum exposure is consistent with this, although measurements of the animals' ambient and internal sulfide exposures will be necessary to fully test this.

Another possible adaptive reason for having high hypotaurine (and a high $\mathrm{H}+\mathrm{Th}$ ) is oxidative stress (Pruski et al. 2000a). Oxygen-centered (as well as sulfur-centered) radicals are generated in the presence of HS', trace metal catalysts, and oxygen (Tapley et al. 1999). Hypotaurine is a strong antioxidant and can react with oxygen radicals (Aruoma et al. 1988). Whether the animals in this study with the highest hypotaurine contents are exposed to greater oxidative stress is uncertain, though the higher metabolic rate of $C$. (V.) pacifica compared to C. kilmeri (Barry et al. 1997) may generate more oxygen radicals.

\section{Taurine and Other Taurine Derivatives}

Taurine contains correlated roughly with depth of collection. This is a trend seen in several previous studies (Pruski et al. 2000a; Fiess et al. 2000) including animals without endosymbionts (Yancey et al. 2004: Rosenberg et al. 2006). The trend has been attributed to a reduction in dietary source of taurine with depth (Pruski et al. 2000a). However, shallow solemyid clams (which have symbionts) interconvert taurine, hypotaurine and thiotaurine (Joyner et al. 2003), and larvae of at least one bivalve species can synthesize taurine de novo (Welborn \& Manahan 1995). Thus a dietary source of taurine itself is not necessarily required in all mollusks. Other reasons for reduction in taurine with depth (e.g., (e.g., high pressure inhibition of reactions involved in taurine synthesis) need to be considered.

The other major taurine derivatives, N-methyltaurine in Ridgeia, and possibly N-methylhypotaurine in Riftia, are unusual in that they have not been reported at osmotically significant levels in other marine invertebrates except for Lamellibrachia vestimentiferans (Yin et al. 2000). Their functions are unknown, but they may be an adaptation to pressure. Other methyated amines have been found to increase with depth in other organisms, and those solutes can stabilize proteins against inhibition by high pressure (Yancey et al. 2004; Yancey 2005).

\section{Conclusions}

Hypotaurine $(\mathrm{H})$ and thiotaurine $(\mathrm{Th})$ together are among the most abundant of all organic compounds in some vent and seep animals, but not in other marine invertebrates. Thus it is important to understand their function. This seems to be their ability to detoxify sulfide for basic cytoprotection and/or storage for thiotrophic symbionts (Alberic \& Boulegue 1990; Pranal et al. 1995; Pruski et al. 2000b). The ratio of $\mathrm{Th} /[\mathrm{H}+\mathrm{Th}]$ increases with sulfide exposure in most species, and may serve as a rough indicator of such 
exposure in intraspecies studies. However, for interspecies comparisons, the ratio should be interpreted within the context of the total $\mathrm{H}+\mathrm{Th}$, which may be an indicator of the maximum sulfide exposure for each species or significantly different phenotype within a species.

\section{Acknowledgements}

For access to cruises and specimens, we are grateful to Lisa Levin (Scripps Institution of Oceanography; West Coast and Polar Regions Undersea Research Center grant UAF 00-0050); Patrick Whaling and James Barry (Monterey Bay Aquarium Research Institute); Kim Juniper (University of Quebec at Montreal), Deb Kelley and John Delaney (University of Washington); and crews of the CCGS John $P$. Tully, R/V Thomas G. Thompson, R/V Point Lobos, and pilots of the DSRVs Alvin, Oceanic Explorer, ROPOS, Ventana and Jason. Funding for Ridgeia piscesae collection was grant UAF01-0042 from NOAAWest Coast National Undersea Research Center to Stephen W. Schaeffer, Charles R. Fisher, and Stéphane Hourdez. Funding for GLB, RVH and PHY was the W.M. Keck Foundation (grant to Whitman College Life Sciences program) and Whitman College Perry Grant program. Funding was from Ifremer for NLB, and The David and Lucile Packard Foundation for SKG.

\section{References}

Alberic P. (1986) Occurrence of thiotaurine and hypotaurine in the tissues of Riftia pachyptila. Comptes Rendus de l'Académie des Sciences Paris, 302, 503-508.

Alberic P., Boulegue J. (1990) Unusual amino compounds in the tissues of Calyptogena phaseoliformis (Japan Trench): Possible link to symbiosis. Progress in Oceanography, 24, 89-101.

Arndt C., Gaill F., Felbeck J. (2001) Anaerobic sulfur metabolism in thiotrophic symbioses. The Journal of Experimental Biology, 204, 741-750.

Arp A.J., Childress J.J., Vetter R.D. (1987) The sulfide binding protein in the blood of Riftia pachyptila is the extracellular hemoglobin. The Journal of Experimental Biology, 128, 139-158.

Aruoma O.I., Halliwell B., Hoey B.M., Butler J. (1988) The antioxidant action of taurine, hypotaurine, and their metabolic precursors. Biochemical Journal, 25, 251-255.

Barry J.P., Greene H.G., Orange D.L., Baxter C.H., Robison B.H., Kochevar R.E., Nybakken J.W., Reed D.L., McHughs C.M. (1996) Biologic and geologic characteristics of cold seeps in the Monterey Bay, California. Deep-Sea Research, 43, 1739-1762.

Barry J.P., Kochevar R.E., Baxter C.H. (1997). The influence of pore-water chemistry and physiology on the distribution of vesicomyid clams at cold seeps in Monterey Bay: Implications for patterns of chemosynthetic community organization. Limnology and Oceanography, 42, 318-328.

Black M.B., Halanych K.M., Maas P.A.Y., Hoch W.R., Hashimoto J., Desbruyeres D., Lutz R. A., Vrijenhoek R.C. (1997) Molecular systematics of vestimentiferan tubeworms from hydrothermal vents and cold-water seeps. Marine Biology, 130, 141-149.

Black M.B., Trivedi A., Maas P.A.Y., Lutz R.A., Vrijenhoek R.C. (1998) Population genetics and biogeography of vestimentiferan tube worms. Deep-Sea Research II, 45, 365-382.

Carney S.L., Peoples J.R., Fisher C.R., Schaeffer S.W. (2002) AFLP analyses of genomic DNA reveal no differentiation between two different phenotypes of the vestimentiferan tubeworm, Ridgeia piscesae. Cahiers de Biologie Marine, 43, 363-366. 
Carney S.L., Flores J.F., Orobona K.M., Butterfield D.A., Fisher C.R., Schaeffer S.W. (submitted) Environmental differences in hemoglobin gene expression in the hydrothermal vent tubeworm, Ridgeia piscesae. Comparative Biochemistry and Physiology.

Cavallini D., Mondovi B., DeMarco C. (1963) Hypotaurine and thiotaurine. Biochemical Preparations, 10, 72-75.

Childress J.J., Arp A.J., Fisher C.R. (1984) Metabolic and blood characteristics of the hydrothermal vent tube-worm Riftia pachyptila. Marine Biology, 83: 109 - 124.

Childress J.J., Fisher C.R., Favuzzi J.A., Arp A.J., Oros D.R. (1993) The role of zinc based, serum-borne sulfide-binding component in the uptake and transport of dissolved sulphide by chemoautotrophic symbioant-containing Calyptogena elongata. The Journal of Expermintal Biology, 179, 131-158.

Distel D.L., Lee H.K-W., Cavanaugh C.M. (1995) Intracellular coexistence of methano- and thioautotrophic bacteria in a hydrothermal vent mussel. Proceedings of the National Academy of Sciences USA, 92, 95989602.

Felbeck H., Childress J.J., Somero G.N. (1981) Calvin-Benson cycle and sulphide oxidation enzymes in animals from sulphide-rich habitats. Nature, 293, 291-293.

Fiess J.C., Hudson H.A., Hom J.R., Kato C., Yancey P.H. (2002) Phosphodiester amine, taurine and derivatives, and other osmolytes in vescomyid bivalves: correlations with depth and symbiont metabolism. Cahiers de Biologie Marine, 43, 337-340.

Fisher C.R. (1990) Chemoautotrophic and methanotrophic symbiosis in marine invertebrates. CRC Critical Reviews in Aquatic Sciences, 2, 399-436.

Fisher C.R., Childress J.J., Oremland R.S., Bidegare R.R. (1987) The importance of methane and thiosulfate in the metabolism of the bacterial symbionts of two deep-sea mussels. Marine Biology, 96, 5972.

Goffredi S.K., Childress J.J., Desaulniers N.T., Lallier F.H. (1997) Sulfide acquisition by the vent worm Riftia pachyptila appears to be via uptake of $\mathrm{HS}^{-}$, rather than $\mathrm{H}_{2} \mathrm{~S}$. The Journal of Experimental Biology, 200, 2609-2616.

Goffredi S.K., Barry J.P. (2002) Species-specific variation in sulfide physiology between closely related vesicomyid clams. Marine Ecology Progress Series, 225, 227-238.

Goffredi S.K., Barry J.P., Buck K.R. (2004). Vesicomyid symbioses from Monterey Bay (central California) cold seeps. Symbiosis, 3, 1-27.

Govenar B., Le Bris N., Gollner S., Glanville J., Aperghis A.B., Hourdez S., Fisher C.R. (2005) Epifaunal community structure associated with Riftia pachptila aggregations in chemically differerent hydrothermal vent habitats. Marine Ecology Progress Series, 305, 67-77.

Joyner J.L., Peyer S.M., Lee R.W. (2003) The possible role of sulfur-containing amino acids in sulfide detoxification in a chemoautotrophic bacteria/mollusc symbiosis. Biological Bulletin, 205, 331-338.

Kraus D.W. (1995) Heme proteins in sulfide-oxidizing bacteria/mollusc symbioses. American Zoologist, 35, 112-120.

Kraus D.W., Doeller J.E., Powell C.S. (1996) Sulfide may directly modify cytoplasmic hemoglobin deoxygenation in Solemya reidi gills. The Journal of Experimental Biology, 199, 1343-1352.

Le Bris N., Govenar B., Le Gall C., Fisher C.R. (2006) Variability of physico-chemical conditions in $9^{\circ} \mathrm{N}$ EPR diffuse flow vent habitat, Marine Chemistry 98, 167-182. 
Levin L.A., Ziebis W., Mendoza1 G.F., Growney V.A., Tryon M.D., Brown K.M., Mahn C., Gieskes J.M., Rathburn A.E. (2003) Spatial heterogeneity of macrofauna at northern California methane seeps: influence of sulfide concentration and fluid flow. Marine Ecology Progress Series, 265, 123-139.

Menon J., Willsie J.K., Tauscher A., Arp A.J. (2003) Epidermal ultrastructure and implications for sulfide tolerance in six species of deep-sea polychaetes. Invertebrate Biology, 122, 334-346.

Page H.M., Fiala-Medioni A., Fisher C.R., Childress J.J. (1991) Experimental evidence for filter-feeding by the hydrothermal vent mussel, Bathymodiolus thermophilus. Deep-Sea Research, 38A, 1455-1461.

Peek A.S., Feldman R.A., Lutz R.A., Vrijenhoek R.C. (1998) Cospeciation of chemoautotrophic bacteria and deep sea clams. Proceedings of the National Academy of Sciences USA, 95, 9962-9966.

Pflugfelder B., Fisher C.R., Bright M. (2005) The color of the trophosome: elemental sulfur distribution in the endosymbionts of Riftia pachyptila (Vestimentifera; Siboglinidae). Marine Biology, 146, 895-901.

Powell M.A., Somero G.N. (1986) Adaptations to sulfide by hydrothermal vent animals: Sites and mechanisms of detoxification and metabolism. Biological Bulletin, 171, 274-290.

Pranal V., Fiala-Médioni A., Colomines, J.C. (1995) Amino acid and related compound composition in two symbiotic mytilid species from hydrothermal vents. Marine Ecology Progress Series, 119, 155-166.

Pruski A.M., Fiala-Medioni A., Colomines J.C. (2000b) Thiotaurine is a biomarker of sulfide-based symbiosis in deep-sea bivalves. Limnology and Oceanography, 45, 1860-1867.

Pruski A.M., Fiala-Médioni A., Fisher C.R., Colomines J.C. (2000a) Composition of free amino acids and related compounds in invertebrates with symbiotic bacteria at hydrocarbon seeps in the Gulf of Mexico. Marine Biology, 136, 411-420.

Pruski A.M., Fiala-Medioni A. (2003) Stimulatory effect of sulfide on thiotaurine synthesis in three hydrothermal-vent species from the East Pacific Rise. The Journal of Experimental Biology, 206, 29232930.

Robigou, V., Delaney J.R., Stakes D.S. (1993) Large massive sulfide deposits in a newly discovered active hydrothermal system, the High-Rise Field, Endeavor Segment, Juan de Fuca Ridge. Geophysical Research Letters, 20, 1887-1890.

Rosenberg N.K., Lee R.W., Yancey P.H. (2006) High contents of hypotaurine and thiotaurine in hydrothermal-vent gastropods without thiotrophic endosymbionts. Journal of Experimental Zoology, 305A, 655-662.

Sarrazin J., Robigou V., Juniper S.K., Delaney J.R. (1997) Biological and geological dynamics over four years on a high-temperature sulfide structure at the Juan de Fuca Ridge hydrothermal observatory. Marine Ecology Progress Series, 153, 5-24.

Shank T.M., Fornari D.J., Von Damm K.L., Lilley M.D., Haymon R.M., Lutz R.A. (1998) Temporal and spatial patterns of biological community development at nascent deep sea hydrothermal vents $\left(9^{\circ} 50^{\prime} \mathrm{N}\right.$, East Pacfic Rise). Deep Sea Research II, 45, 465-515.

Southward E.C., Tunnicliffe V., Black M. (1995) Revision of the species of Ridgeia from northeast Pacific hydrothermal vents, with a redescription of Ridgeia piscesae Jones (Pogonophora: Obturata = Vestimentifera). Canadian Journal of Zoology, 73, 282-295.

Southward E.C., Tunnicliffe V., Black M.B., Dixon D.R., Dixon L.R.J. (1996) Ocean-ridge segmentation and vent tubeworms (Vestimentifera) in the NE Pacific. Tectonic, Magmatic, Hydrothermal and Biological Segmentation of Mid-Ocean Ridges, 118, 211-224. 
Tapley D.W., Buettner G.R., Shick J.M. (1999) Free radicals and chemiluminescence as products of the spontaneous oxidation of sulfide in seawater, and their biological implications. Biological Bulletin, 196, 5256.

Urcuyo I.A., Massoth G.J., MacDonald I.R., Fisher C.R. (1998) In situ growth of the vestimentiferan Ridgeia piscesae living in highly diffuse flow environments in the main Endeavour Segment of the Juan de Fuca Ridge. Cahiers de Biologie Marine, 39, 267-270.

Urcuyo I.A., Massoth G.J., Julian D., Fisher C.R. (2003) Habitat, growth and physiological ecology of a basaltic community of Ridgeia piscesae from the Juan de Fuca Ridge. Deep Sea Research Part I: Oceanographic Research Papers, 50, 763-780.

Van Dover C.L., Fry B. (1994). Microorganisms as food resources at deep-sea hydrothermal vents. Limnology and Oceanography, 39, 51-57.

Vetter R.D. (1985) Elemental sulfur in gills of three species of clams containing chemoautotrophic bacteria: a possible inorganic energy storage compound. Marine Biology, 88, 33-42.

Welborn J., Manahan D. (1995) Taurine metabolism in larvae of marine invertebrate molluscs (Bilvalvia, Gastropoda). The Journal of Experimental Biology, 198, 1791-1799.

Wolff S., Yancey P.H., Stanton T.S., Balaban R. (1989) A simple HPLC method for quantitating the major organic solutes of the renal medulla. American Journal of Physiology, 256, F954-956.

Yancey P.H. (2005) Organic osmolytes as compatible, metabolic, and counteracting cytoprotectants in high osmolarity and other stresses. The Journal of Experimental Biology, 208, 2819-2830.

Yancey, P.H., Blake W., Conley J. (2002) Unusual organic osmolytes in deep-sea animals: Adaptations to hydrostatic pressure and other perturbants. Comparative Biochemistry and Physiology, 133A, 667-676.

Yancey P.H., Rhea M.D., Kemp K.M., Bailey D.M. (2004) Trimethylamine oxide, betaine and other osmolytes in deep-sea animals: depth trends and effects on enzymes under hydrostatic pressure. Cellular and Molecular Biology, 50, 371-376.

Yin M., Palmer H.R., Fyfe-Johnson A.L., Bedford J.J., Smith R.A.J., Yancey P.H. (2000) Hypotaurine, Nmethyltaurine, taurine, and glycine betaine as dominant osmolytes of vestimentiferan tubeworms from hydrothermal vents and cold seeps. Physiological and Biochemical Zoology, 73, 629-637.

Zal F., Leize E., Oros D.R., Hourdez S., Dorsselaer A.V., Childress J.J. (2000) Hemoglobin structure and biochemical characteristics of sulphide-binding component from the deep-sea clam Calyptogena magnifica. Cahiers de Biologie Marine, 41, 413-423. 


\section{Figures}

Fig. 1. Ratios of thiotaurine to sum of hypotaurine and thiotaurine $(\mathrm{Th} /[\mathrm{H}+\mathrm{Th}])$ for symbiont-bearing tissues, from Table 1. "1" and "2" designate specimens with higher and lower sulfide exposures, respectively. Values are means $\pm 1 \mathrm{SD}$; *different from the same species at the other seep or vent site; tdifferent from the other species at the same seep $(p<0.05)$.

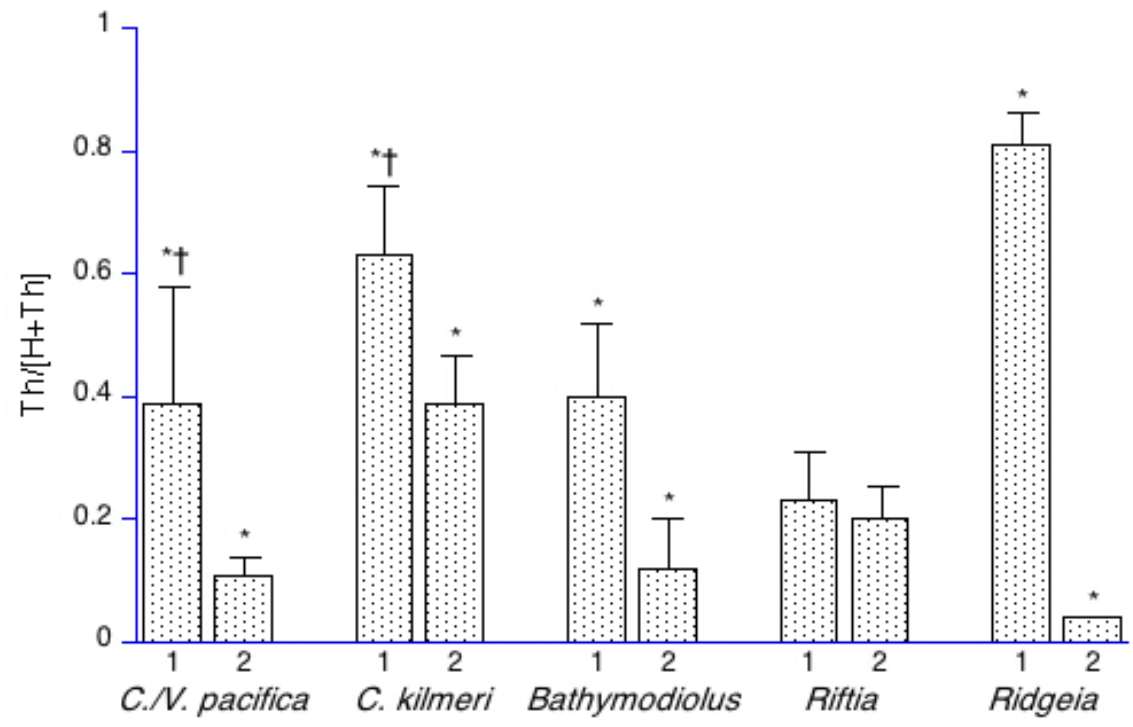


Fig. 2. Sum of hypotaurine and thiotaurine $(\mathrm{H}+\mathrm{Th})$ for symbiont-bearing tissues, from Table 1 . Values are means $\pm 1 \mathrm{SD}$; *different from the same species at the other seep or vent site; †different from the other species at the same seep $(p<0.05)$.

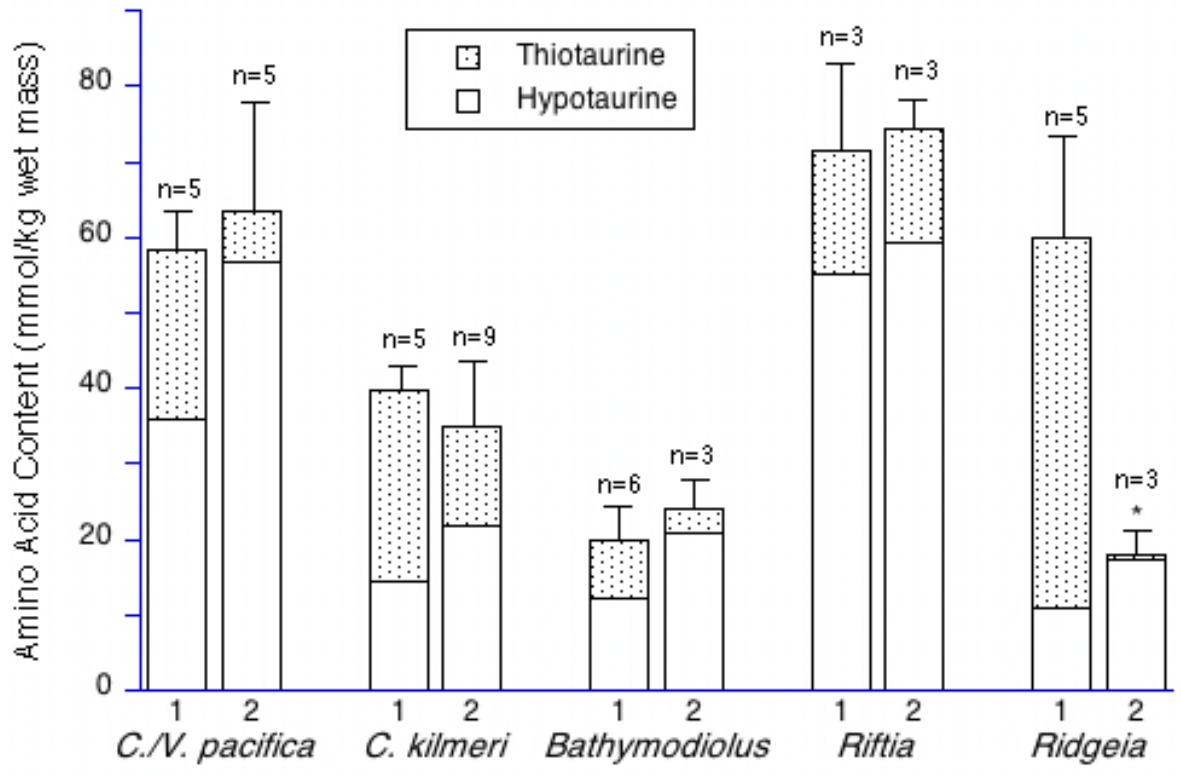

